\title{
Trends in James Baldwin Criticism 2001-10
}

\author{
Lynn Orilla Scott Michigan State University
}

\begin{abstract}
James Baldwin criticism from 2001 through 2010 is marked by an increased appreciation for Baldwin's entire oeuvre including his writing after the mid1960s. The question of his artistic decline remains debated, but more scholars find a greater consistency and power in Baldwin's later work than previous scholars had found. A group of dedicated Baldwin scholars emerged during this period and have continued to host regular international conferences. The application of new and diverse critical lenses-including cultural studies, political theory, religious studies, and black queer theory-contributed to more complex readings of Baldwin's texts. Historical and legal approaches re-assessed Baldwin's relationship to the Civil Rights and Black Power movements and new material emerged on Baldwin's decade in Turkey. Some historical perspective gave many critics a more nuanced approach to the old "art" vs. "politics" debate as it surfaced in Baldwin's initial reception, many now finding Baldwin's "angry" work to be more "relevant" than "out of touch" as it was thought of during his lifetime. In the first decade of the new millennium, three books of new primary source material, a new biography, four books of literary criticism, three edited collections of critical essays, two special issues of journals and numerous book chapters and articles were published, marking a significant increase not only in the quantity, but the quality of Baldwin criticism.
\end{abstract}

Keywords: James Baldwin, literary criticism (2001-10), African-American literature, biography, queer theory

The first decade of the new millennium brought an increased interest in Baldwin's life and work among scholars from diverse fields, mostly literary and cultural studies, but also political science, legal studies, philosophy, history, and journalism. This period is marked by a greater interest in Baldwin's complete oeuvre, and

James Baldwin Review, Volume 2, 2016 @ The Authors. Published by Manchester University Press and The University of Manchester Library 
a better appreciation of the complexity of his thought. The quantity of criticism remained smaller than for other major twentieth-century African-American writers, especially in the first half of this decade. ${ }^{1}$ However, the quality improved, and during this time a dedicated group of Baldwin scholars began promoting new work by organizing conferences on Baldwin and editing collections of articles in books and special editions of journals. Those scholars include D. Quentin Miller, Dwight McBride, Douglas Field, Magdalena Zaborowska, and others listed as editors of this journal.

The decade opened with an important public tribute to Baldwin. On 1 February 2001 the "Twentieth-Century Masters Tribute to James Baldwin" was held at Lincoln Center in New York featuring talks by Nikki Giovanni, Russell Banks, Amiri Baraka, John Edgar Wideman, Hilton Als, David Leeming and others. The event, co-sponsored by PEN American Center, the Schomburg Center for Research in Black Culture, and The New Yorker, continues to be available online for listening. ${ }^{2}$ Talks given at this tribute were published in "James Baldwin's Grand Tour" in PEN America: A Journal for Writers and Readers. ${ }^{3}$ In February 2000 Howard University held the conference, "Challenging American Sociopolitical Hierarchy: James Baldwin at the Millennium," to reassess Baldwin's achievement by focusing on all facets of his canon. In March 2003 Goucher College in Baltimore, MD, held a daylong symposium to celebrate fifty years of Go Tell It on the Mountain, titled, "Go Tell It! Claiming the Baldwin Tradition," with keynote speaker bell hooks. Then, in June 2007, Queen Mary University of London hosted the "James Baldwin Work, Life, Legacies" conference which featured keynotes by British and Irish authors Caryl Phillips and Colm Toibin, and drew scholars from several countries. This was the first international biennial conference on Baldwin, sparking a trend which would continue in the U.S. and in France. The second biennial conference was held in 2009 at Suffolk University in Boston; "James Baldwin In His Time/In Our Time” featured keynote speaker David Leeming, James Baldwin's biographer, friend, and secretary, and a performance by Calvin Levels, "James Baldwin: Down from the Mountaintop." The conference re-energized Baldwin studies, bringing together established and newer scholars. D. Quentin Miller published an overview of the conference and five essays in a special edition of Obsidian III: Literature in the African Diaspora. ${ }^{4}$

Between 2001 and 2010 three books of new primary source material and five monographs on Baldwin's work and/or life were published. In addition, there were three edited collections of essays and two special issues of journals devoted to Baldwin's work. ${ }^{5}$ I found at least 34 books with significant chapters or material on Baldwin and an additional 65 articles in scholarly journals not including those in the two special issues. It will not be possible to comment on all of this output in the scope of this article, but I will hit on highlights and trends as I see them.

Primary sources include The Cross of Redemption: Uncollected Writings (2010), edited by Randall Kenan, which is a companion piece to the Library of America's edition of Baldwin's collected nonfiction. The volume "brings together an eclectic mix of reviews, essays, and public letters from 1947 to 1985 and includes an early 
story, 'The Death of a Prophet."' 6 While the material in this volume had been previously published in various magazines, Kenan has done a great service to Baldwin readers by making it easily available. The inclusion of Baldwin's early book reviews on works as various as Maxim Gorky's short stories and John Hope Franklin's From Slavery to Freedom add to our understanding of Baldwin's development as a cultural critic. Also of particular interest are Baldwin's "Letters from a Journey," his letters from Israel and Turkey to his agent, Robert P. Mills. The volume includes Baldwin's last essay, "To Crush a Serpent" (1987) in which he re-visits his life as an adolescent preacher experiencing the turmoil of sexual awakening; classic Baldwin, but updated to critique the "present-day gang" of fundamentalist preachers (Falwell and Robertson) who "have taken the man from Galilee as hostage", reduced the Bible to "a cowardly system of self-serving pieties," and misunderstood Salvation, which Baldwin tells us is "real."7 "Salvation connects, so that one sees oneself in others and others in oneself." "To Crush a Serpent" is a key essay for those interested in exploring Baldwin's prophetic voice and relationship to Christianity.

Native Sons: A Friendship That Created One of the Greatest Works of the Twentieth Century: Notes of a Native Son (2004) includes previously unpublished photographs and correspondence between Sol Stein and Baldwin from the mid to late 1950s, and two previously unpublished works that they wrote together, a story, "Dark Runner," and a play, "Equal in Paris," based on Baldwin's essay of that title. Stein, who had been Baldwin's longtime friend and schoolmate, edited and arranged for the production of Notes of a Native Son at Beacon Press. The letters provide a rich context for Giovanni's Room as well as Notes for a Native Son, and insight into Baldwin's life and friendships during his early years as a published writer. Baldwin's Turkish friend, Engin Cezzar, published his correspondence with James Baldwin in 2007, translated into Turkish as Dost Mektuplari. The letters run from the late 1950s to the mid-1970s, providing a window on Baldwin's hectic life as a transatlantic commuter, his efforts to bring Giovanni's Room to the stage, the writing of Another Country through If Beale Street Could Talk, and Baldwin's intervention on behalf of his former bodyguard and friend, Tony Maynard, who was falsely imprisoned.

The critical monographs on Baldwin published during this decade are Lawrie Balfour's The Evidence of Things Not Said: James Baldwin and the Promise of American Democracy (2001); Lynn Orilla Scott's James Baldwin's Later Fiction: Witness to the Journey (2002); Clarence Hardy's James Baldwin's God: Sex, Hope and Crisis in Black Holiness Culture (2003); Herb Boyd's Baldwin's Harlem: A Biography of James Baldwin (2008); and Magdalena Zaborowska's James Baldwin's Turkish Decade: Erotics of Exile (2009). Each of these books focuses on different aspects of Baldwin's work and life, opening up new directions in Baldwin scholarship.

In her beautifully written The Evidence of Things Not Said: James Baldwin and the Promise of American Democracy (2001), Laurie Balfour, a political scientist, makes a persuasive case for Baldwin's importance to democratic theory. Baldwin, she argues, anticipates the limitations of American civil rights legislation, especially 
the ways in which the presumption of race blindness would support ongoing racial hierarchy. Baldwin's exploration of race consciousness, that is "the ways that whiteness and blackness are noticed (or not noticed) in daily life", according to Balfour, can "provide us a guide in countering the retreat from a national commitment to opposing racial injustice in what has been called the 'post-civil rights era."' Although her focus is on his early essays, Balfour draws from the entirety of Baldwin's corpus, and insists that there is great continuity in his work, rejecting the before-and-after story that had dogged the reception of Baldwin's writing after the mid-1960s, explicitly rejecting claims that his voice broke or that his later essays were too political. With this note, she strikes what will become a theme in much Baldwin criticism. Although the narrative of Baldwin's decline as an artist, sometimes framed as a political capitulation to Black Nationalism, does not exactly disappear after 2000, it is strenuously challenged by many Baldwin scholars. Balfour's short book nicely explicates Baldwin's deft explorations of American innocence and its connection to white privilege, his understanding of the interrelation of racial and sexual identity, his rejection of the image of the black American as victim, and the ways in which African Americans have been rendered "generally visible and individually invisible." ${ }^{10}$ If the liberal American mindset of the twenty-first century can accommodate an apparently "earnest commitment to the principles of equal rights ... and a tacit acceptance of racial division and inequality as normal," then Baldwin, whose work uncovers the underlying assumptions of this contradiction, remains critical not only to democratic theory, but to the ongoing struggle for racial justice, and Balfour's book remains important to the present. ${ }^{11}$

While Balfour claims the importance of Baldwin to democratic theory, George Shulman puts Baldwin at the center of a radical American prophetic tradition that is instructive to American political theory. In American Prophecy: Race and Redemption in American Political Culture (2008), Shulman not only reclaims the role of prophecy in American politics from fundamentalist preachers, but also from American Studies scholars such as Sacvan Bercovitch who view prophetic language as simply an ideology that sustains the liberal national state. Shulman argues that prophecy is an American idiom and social practice open to revision and that blacks-and whites who identify with blacks-"use prophecy to resist white supremacy ... develop a critical view of the liberal faith, jeremiadic form, and national frame that rule American politics." 12 He traces these connections and revisions in substantive readings of Henry David Thoreau, Martin Luther King Jr., James Baldwin, and Toni Morrison. Shulman casts Baldwin's secular prophetic narratives as a construction of the role of the outcast and meaning of love. "Baldwin translates the office of prophecy into the public calling of the artist, which he construes as a lover's responsibility to 'disclose the beloved to himself."'13 Shulman also grapples with the way that Baldwin's messages-like King's-would be "contained" or reduced by political philosophers who see them as exemplars of American exceptionalism. In addition he challenges the claim by literary critics that Baldwin's 1972 memoir, No Name in the Street, is an aesthetic failure. Rather, "it is truer to say the text struggles to come to terms with the defeat of a second 
Reconstruction" and does so by an "exemplary performance of irony" where Baldwin suspends himself and his reader "between Jeremiah and Job."14

An important source for understanding Baldwin's significance to the Civil Rights movement is Divided Minds: Intellectuals and the Civil Rights Movement (2001). Carol Polsgrove charts the reluctance of many prominent white and black American intellectuals to support the civil rights struggle in the early years of the movement, citing Baldwin as the exception. Even though Baldwin didn't hold a position in any of the civil rights organizations, she shows that "by virtue of his frankness, eloquence, and reputation" he became "a spokesman for the movement." ${ }^{15}$ Polsgrove, a journalism professor, places Baldwin's early essays and their reception in the intellectual and political context of the period. She explores Baldwin's relationship to the Cold War, anti-communist politics of the New York magazines and editors for whom he was writing. Then she charts his move away from those early alliances, his critique of liberalism, and the liberal reaction to The Fire Next Time. This is an especially useful source for understanding Baldwin in the context of other public intellectuals of his time and restores Baldwin's key role in the movement for racial justice, a role that has been largely ignored in movement histories that have focused on organizations like the Southern Christian Leadership Conference, Congress of Racial Equality, or the Student Non-Violent Coordinating Committee, although Baldwin certainly had relationships with these organizations and their leaders.

Notably, Polsgrove does not cover Baldwin's engagement after the mid-1960s with the Black Power movement or address the standard narrative of Baldwin's supposed decline. Baldwin does, however, receive some mention in historian Peniel E. Joseph's Waiting 'Til the Midnight Hour: A Narrative History of Black Power in America (2006). Will Walker's “After The Fire Next Time: James Baldwin's Postconsensus Double Bind" (2002) examines Baldwin's complicated relationship to late 1960s Black Nationalism. Walker resists Henry Louis Gates's claim that after The Fire Next Time, Baldwin "became a rhetorical ape of the new black nationalist ideologues," arguing that Gates fails to see the way Baldwin's early writings "anticipated the rhetorical strategies of the Black Power Movement" and that "Baldwin's critical repertoire made him as marginal to the civil rights movement as it did to the Black Power movement." ${ }^{16}$ Walker argues that Baldwin was a "liminal intellectual . . . caught between two definable ideological formations of the black freedom movement of the 1950s and 1960s." ${ }^{17}$ The Fire Next Time was a complex document because it "coupl[ed] the black nationalist negative critique of American democracy with an affirmative hope in the American future."18 Walker goes on to examine No Name in the Street as Baldwin's effort to reinterpret the Civil Rights movement "for a new generation of black nationalist activists." 19

No one resists the narrative of Baldwin's decline more passionately than Bill Lyne in "God's Black Revolutionary Mouth: James Baldwin's Black Radicalism" (2010). Focusing on Baldwin's consistent class allegiance to poor blacks, Lyne rips apart the good Baldwin/bad Baldwin narrative, claiming that "the problem is not that Baldwin relinquished art for politics, but that his politics moved from a stance 
that made him the darling of the white liberal establishment to one that pushed him beyond the boundaries of canonization." ${ }^{20}$ Lyne re-examines Baldwin's quarrel with Richard Wright and "the continuities and differences" between The Fire Next Time and No Name in the Street to read Baldwin's career as "a logical progression" of a radicalism that was present from the beginning in his allegiance to the poor, suspicion of white liberals - and of the black bourgeois-and an underlying economic understanding of the sources of social inequality all present by The Fire Next Time. ${ }^{21}$ Lyne also understands Baldwin's support of the Black Panthers as a natural alliance rather than a desperate effort to be accepted by the younger generation, as Gates and others have suggested. ${ }^{22}$

Brian Norman places Baldwin's essays in a national tradition of protest writing. In The American Protest Essay and National Belonging: Addressing Division (2007), Norman considers the cultural and aesthetic characteristics of the protest essay, drawing from over a dozen nineteenth- and twentieth-century American writers. This tradition, he argues, "bring[s] experiences of exclusion to divided publics" and "offer[s] their divided audience a reinvigorated national 'we' that can account for division within that 'we." 23 In Baldwin's essays, Norman sees the "full flowering of the American protest essay"; he examines Baldwin's changing political reception and questions "pronouncements of Baldwin's post-sixties artistic decline," arguing that "the political climate changed, not necessarily Baldwin's essays." ${ }^{24}$ Norman argues that "one reason that Baldwin's protest essays are not yet fully appreciated in an artistic tradition is that literary criticism tends to assume a split between art and political advocacy and often pits them against each other." ${ }^{25}$

While there seems to be agreement that Baldwin's essays from 1963 onward anticipate the limits of civil rights legislation to bring about racial equality, scholars have had different responses to Baldwin's legal critique in the post-civil rights era. In an essay that compares James Baldwin's book on the Atlanta murders, Evidence of Things Not Seen (1985), with two of Toni Morrison's essays from the 1990s, Richard Schur argues that Baldwin "recast legalized racism as a sensory problem, rather than one of rationality" and that in Evidence, Baldwin would "shift the attention of civil rights activists from legal substance to legal process." ${ }^{26}$ Unlike Morrison, who Schur argues is less optimistic about the efficacy of legal discourse, Baldwin's "analysis reflects a faith ... [that] legal discourse could arrive at properly equitable and just results." ${ }^{27}$ Deak Nabers, contra Schur, sees a problematic shift from legal and social concerns to historical concerns in Baldwin's writing about racial inequality. In this shift, Nabers finds a "mirror" of President Lyndon Johnson's thinking, which also sought historical explanations for the limits of civil rights legislation to address racial inequality. But this shift, according to Nabers, results in "obscur[ing] ongoing structural racial inequality rather than bringing it into focus." 28 He claims that "Baldwin's knotted dual imperative of transcending and embracing history remains a staple of critical civil rights discourse to this day." ${ }^{29}$ Nabers, though, does not celebrate this legacy since he sees Baldwin and by extension those who have inherited this turn to history as "wrong in thinking that their solutions are anything other than a performance of the problem." ${ }^{0}$ 
He says, "Our ongoing obsession with history simply perpetuates the logic which displaces our attention from the practical, instrumental, legal questions our civil right problems demand." ${ }^{31}$ Naber's critique echoes some of the initial criticism of The Fire Next Time, which lamented its lack of more pragmatic solutions to the racial crisis. ${ }^{32}$ However, in his "The Fire Next Time and the Law," D. Quentin Miller responds to Naber's analysis by acknowledging that Baldwin is skeptical of legal solutions, because Baldwin sees the law as a "criminal power" which "is still in the hands of the oppressors." ${ }^{33}$ At the same time, Baldwin relies on legal rhetoric throughout Fire, implying that he has not, in fact, turned from social and legal concerns. Near the end of "Down at the Cross," Baldwin writes, "There is simply no possibility of a real change in the Negro's situation without the most radical and far-reaching changes in the American political and social structure." ${ }^{34}$

My book James Baldwin's Later Fiction: Witness to the Journey (2002) builds on D. Quentin Miller's Reviewing James Baldwin: Things Not Seen (2000) and Dwight McBride's James Baldwin Now (1999), which began to look at lesser known texts and apply new approaches to Baldwin's work. In this book, I provide close readings of the last three, largely neglected, novels: Tell Me How Long the Train's Been Gone, If Beale Street Could Talk, and Just Above My Head, and examine their politicized and often homophobic reception. I argue that these later novels should "not be read as evidence of either a political capitulation or an artistic decline, but as evidence of the ways Baldwin creatively responded to a changing racial environment and discourse," and place them in contexts of African-American creative forms, Baldwin's earlier novels, and his nonfiction. ${ }^{35}$ Using Robert Stepto's structuralist approach, I look at the way Train signifies a long tradition of black male autobiography, as well as its revisionary relationship to Go Tell It on the Mountain. Critics who disliked Train for its supposed endorsement of black militancy missed the ways that the novel challenges both American liberalism and the homophobic and masculinist discourse of late 1960s Black Nationalism. I examine Beale Street as a novel written in response to the right turn in American politics. In this novel Baldwin explores sources of a resistant black blues culture in the solidarity of a secular black family. The novel bears a revisionary relationship to Go Tell on several levels, but especially in its depiction of the Church, the family, and the trope of "illegitimacy." The figure of the black artist emerges, as Houston Baker put it, as an "engaged craftsman" whose work merges personal and social transformation. ${ }^{36}$ But disturbingly, Baldwin's sacralization of heterosexual love employs, at times, a homophobic and patriarchal discourse. I read Just Above My Head as Baldwin's attempt to address his own legacy; the four main characters are a composite of the author's attitudes, experiences, fears, and hopes. Extending Eleanor Traylor's reading of the novel as a storyteller's novel told in a musical mode, I read JAMH's narrative voice as representing the communal ethos of the oral storytelling tradition, and place the novel's repetitious and additive structure as analogous to the musical forms that inspire it. ${ }^{37}$

The significance of Baldwin's late fiction continues to be contested. When we examine Baldwin's writing after the mid-1960s do we find "a rich intellectual 
journey that illustrates the direction of African American thought and culture," as D. Quentin Miller would have it, or do we find that the vicious homophobic attacks Baldwin experienced-especially within the Black Arts movement-had a "devastating" and "profound effect on Baldwin's writing," as Douglas Field would have it? ${ }^{38}$ Throughout the decade, this question is at the heart of much of the writing on Baldwin's later work. Critics exploring Baldwin's later novels are frequently focused on his depictions of black masculinity, sexuality, and the possibilities of racial community. Important critiques of Baldwin's late novels can be found in Keith Clark's Black Manhood in James Baldwin, Ernest J. Gaines, and August Wilson (2002); Rolland Murray's Our Living Manhood: Literature, Black Power, and Masculine Ideology (2007); and Robert Reid-Pharr's Once You Go Black: Choice, Desire, and the Black American Intellectual (2007), as well as in a few articles. Those critics working with the later fiction each respond in one way or another to the narrative of Baldwin's decline and to his fraught relationship with Black Nationalism.

Keith Clark argues that "Baldwin goes to great lengths to penetrate the relationships between black men-a topic that had been underexamined in black fiction." ${ }^{39}$ He pairs the early story, "Sonny's Blues" (1957), with Baldwin's last novel, Just Above My Head (1979), because of their thematic and structural intertextuality, noting that "Sonny's Blues" is atypical for its "absence of psychosexual conflict," while $J A M H$ returns to "familiar fictive terrain." ${ }^{0}$ He states that JAMH "represents a melding of the homosocial and the homosexual" and goes on to investigate Baldwin's "homopoetics," that is, his aesthetic position on literary representations of homosexuality. ${ }^{41}$ Baldwin, he argues, consistently contests a "homonormative discourse which frequently privileges sexual difference as the self's single most significant component," and Clark interprets Baldwin's 1984 interview with Richard Goldstein, when Baldwin claimed that the term gay "rubbed me the wrong way," as Baldwin's refusal to allow "his racial identity to be subsumed within AngloAmerican queer discourse, which obviates racial and other realities." 42 Clark goes on to analyze JAMH as "a textual and sexual conundrum ... that raises as may questions as it answers." ${ }^{43}$ He basically follows Melvin Dixon's earlier line of criticism of the novel, claiming that "Hall's narration becomes a subterfuge that muffles his brother's voice," and laments that "perhaps Baldwin could not translate his resonant, uncompromising conception of his own gay subjectivity into his fiction." ${ }^{4}$ Oddly, Clark's critique of JAMH seems to reverse his earlier approval of Baldwin's homopoetics as a refusal to privilege sexual difference over other components of one's identity. While Goldstein wanted Baldwin to claim the identity "gay," Clark wants Baldwin to claim the identity "black gay writer." Baldwin's decision to tell Arthur's story (mostly) through Hall's black heteronormative gaze is, for Clark, evidence of Baldwin's “irreconcilable anxiety about fictionalizing black sexual difference" rather than another example of Baldwin resisting limiting identity categories. ${ }^{45}$

Rolland Murray's book examines the challenge to Black Power's masculinist politics in the works of six African-American authors writing during the heyday 
of the movement. He describes the different strands of nationalism as bourgeois, Marxist, and cultural, and points out that each "evoked masculine selfhood" in varied and competing ways; thus "masculinity took on ... multiple ideological meanings" and resulted in significant disagreement at the time. ${ }^{46}$ By looking at neglected literary works that link writers to the Black Power movement, Murray hopes to "reconfigure the cultural history of the period and the literary biographies of individual authors." ${ }^{47}$ His analysis of Baldwin's relationship to Black Power both challenges and rehearses some of the conventional wisdom. On the one hand, Murray disagrees with critics who claim that Baldwin lost his individualist voice by surrendering to the dogmatism of Black Power. They have ignored evidence of Baldwin's skepticism and dissent. For Murray, the neglect of Tell Me How Long the Train's Been Gone has resulted in "the oversimplification of Baldwin's ties to Black Power." 48 The novel offers "an acute critical assessment of the very solidarity with black radicals that he promoted elsewhere." 49 On the other hand, Murray does see Baldwin as becoming increasingly invested in masculinist and patriarchal politics, contrasting his earlier willingness to criticize the Nation of Islam in The Fire Next Time to his public embrace of Black Power.

Like others, Murray interprets Baldwin's response in No Name in the Street to Eldridge Cleaver's homophobic attack on him as basically legitimizing Cleaver's sexual logic..$^{50}$ Murray dismisses If Beale Street Could Talk as "utterly phallic and patriarchal," evidencing a devolution in Baldwin's gender analysis from Go Tell It on the Mountain, where Baldwin "had once mapped the restrictive logic of patriarchal social arrangements" to a rewriting of "patriarchy as a source of security, stability, and continuity." ${ }^{51}$ Keith Clark also dismisses Beale Street as "mawkishly extoll[ing] the virtues of heterosexual love" and "a paean to anachronistic constructions of black manhood." 52 Both Murray and Clark read Baldwin's use of a female narrator in that novel as an inauthentic appropriation of female subjectivity, Clark calling it "narrative transvestism." 53 Important to Murray's analysis is his sense of an underlying tension between Baldwin's earlier criticism of patriarchy and his privileging of masculine subjectivity as a source of emancipation:

The construction of a new kind of masculine subjectivity is elemental in Baldwin's identity politics. It is the "manhood" of the male subject that is imperiled by a history of white supremacist tyranny. Baldwin does not necessarily advocate the return of patriarchy with its coterie of paternal laws and rituals, but he does seem to long for the reproduction of a specifically masculine authority. When Baldwin links his alternative notions of selfhood to "unshakable authority" and "manhood," he contradicts his more radical notion of the self as an engaged critic whose identity would necessarily be in constant flux..$^{54}$

Robert Reid-Pharr takes up Baldwin's last novel in Once You Go Black. ReidPharr "draw[s] together the insights of Black American cultural and literary criticism with those of queer theory" to make a passionate and ethical argument about the centrality of choice in black American identity. ${ }^{55}$ The pernicious idea 
of the black American as a victim who lacks choice is "deeply embedded within the American common sense." ${ }^{56}$ Reid-Pharr wants his readers to take seriously the idea "that current generations of Americans are indeed agents and not simply products of history ... If one can imagine a prototypical Black American subject, then it is surely he who struggles to choose his own work, home, family, his own destiny." ${ }^{57} \mathrm{He}$ calls for a rigorous historicism in the study of black literature and history, claiming that the tendency to treat the black tradition as sacred "underwrites logics of segregation and apartheid." 58 Foregrounding choice and historical contingency, Reid-Pharr reads the late works of Wright, Ellison, and Baldwin as novels which refuse to represent blacks as simply victims. In each of their late works, "they reject the notion of the black as innocent and instead insist upon his modernity and thus responsibility within modern society. In so doing they challenge notions of an already decided black identity." 59 These later works have gotten little attention due to the belief that they were products of the artist in decline, but the very notion of "the artist in decline," Reid-Pharr suggests, is linked to expectations that black artists should be representative. Resisting dismissals of Baldwin as having succumbed to sloganeering or lost control of his craft, Reid-Pharr argues that Baldwin attempted "to come to terms with the changing social, political, and ideological realities of the universe he was trying to map," and that he is an "interesting, even indispensable, novelist because his career was so closely tied to the rapid changes that took place in the mid-twentieth century in relation to the question of black and American identity." ${ }^{\circ 0}$

Reid-Pharr reads Just Above My Head as Baldwin's concern with "the passing of a certain sense of personal and communal intimacy," intimacies previously associated in Baldwin's work with church, family, race, and sex that "can no longer and indeed never could be certain." ${ }^{1}$ Refusing the mantle of Black Nationalism, Baldwin takes up a workable identity of "remembering and forgetting" and gospel music is his metaphor for this process. ${ }^{62}$ "Decline," Reid-Pharr claims, is a major theme in the novel and black American cultural practices are a formal response to this process of decline. Baldwin pairs homosexuality and gospel in an effort to produce a type of "alienation in his reader, to disrupt the often precious manner in which we think about black American identity," and in so doing he gives back to his reader freedom of choice: "Once our traditions have been sullied, once they carry the taint of an all-too-modern homosexual funkiness, it becomes that much more apparent that we are continually in a process of choosing whether and how to continue those traditions." ${ }^{33}$ JAMH is not only about choosing black identity, but about the social death of those who are loved too much, who are consumed by the public, the martyrs, the singers. In Arthur's death, the reader finds Baldwin's "unlikely protest," which is, according to Reid-Pharr, that "the privacy and sacredness of the individual and the individual's body must be maintained even and especially at the moment at which that individual offers up his own life story as a potent metaphor for the reality and the promise of the human condition." ${ }^{44}$ Still, he concludes, JAMH is not a pessimistic novel, as it ends with Hall and Julia's move into a middle-class life. For Reid-Pharr, Baldwin's lesson is “we cannot always live 
alienated from our alienation. We must eventually come to embrace all that we are, including those parts of us that are shallow and perhaps even cruel if we are ever to reach the beloved community that we all imagine floating out there just above our heads." 65

Brian Norman's essay, “James Baldwin's Confrontation with US Imperialism in If Beale Street Could Talk," has done more than any other critique of this novel to enhance our appreciation of Baldwin's continuing critical engagement with identity politics. As noted in the above discussion, even those who wish to reclaim Tell Me How Long the Train's Been Gone and Just Above My Head tend to dismiss Beale Street as a homophobic, sexist, and sentimental tribute to the black family in line with the politics of Black Nationalism. Norman, on the other hand, in a very persuasive reading of the key scenes in Puerto Rico, argues that the novel is a "complex attempt to understand domestic racial self-determination in the context of US imperialism." ${ }^{66}$ Unlike Paule Marshall's Praise Song for the Widow, to which Norman draws a productive contrast, Baldwin's novel "rejects easy gestures toward diasporic unity." ${ }^{\prime \prime}$ Through the character of Sharon we see the appeal to a shared blackness and a shared womanhood fail to persuade Victoria, a poor Puerto Rican woman, to return to the U.S. to help exonerate Fonny. Victoria sees Sharon not as a fellow black but as a North American (privileged) lady. Sharon is "unexpectedly thrust into an imperialist position," claims Norman, and he concludes: "Beale Street may be seen as Baldwin's novel most in line with the goals and sensibilities of the Black Arts movement, yet his representation of failed transnational crossings suggests a resemblance between postures of cultural nationalism, racial pride, and U.S. imperialism." ${ }^{6}$

Other articles on the late fiction deserve mention. Aaron Oforlea's article, "Remaking and Marking Tradition: Black Male Subjectivity in Baldwin's Tell Me How Long the Train's Been Gone," explores acting, in the novel, as "a powerful metaphor for the performance of African American subjectivity ... [whereby mimicry performs] how discourses function socially and culturally." 69 Also notable is Finnish scholar Pekka Kilpelainen's “Transcending the Boundaries of Race and Sexuality: James Baldwin's Vision of Postcategorical Utopia," in which he reads Train as part of Baldwin's ongoing project to develop a "vision of the world in which the categories of race, sexuality, gender, etc., would lose their capacity for oppression."70 Kilpelainen draws on Fredric Jameson's theory of the political unconscious to explore the way Train "articulates many of the crucial social problems and contradictions of the era in which it was written and seeks to resolve them on the level of the imaginary." ${ }^{\prime 1}$ Two additional articles on Just Above My Head look at Baldwin's use of incest as metaphor. Joanna Jeskova's "Incestuous Violence and Brotherly Love in James Baldwin's Just Above My Head" argues that "Baldwin uses incest both as a trope for the history of racism in America and for the necessary path toward healing."72 My own essay, "Revising the Incest Story: Toni Morrison's The Bluest Eye and James Baldwin's Just Above My Head," argues that both novels "expose the ideological uses of incest stories to normalize cultural scripts about race and sex and to render other subjects and stories 'unspeakable," 
although for Morrison the unspeakable subject is racial self-loathing, while for Baldwin it is homophobia. ${ }^{73}$

Although this decade did see an increased interest in Baldwin's later work, his earlier fiction continued to be at the center of the majority of scholarship. A new collection of essays on Go Tell It on the Mountain was published. Giovannis Room became a central text for black queer studies, and Another Country and Go Tell continued to dominate studies of Baldwin's racial and sexual poetics and politics. While I won't be able to mention all of the good work that was done on Baldwin's early novels and short fiction, I will highlight some key pieces.

Carol E. Henderson edited a collection of nine new essays on Go Tell It on the Mountain to celebrate the novel's 50th anniversary in a 2004 special issue of The Middle-Atlantic Writers Association Review (MAWA). ${ }^{74}$ This collection offers new cultural perspectives especially on the politics of gender, sexuality, race, and spirituality, as well as claims for the novel's West African cultural retentions. Henderson explores the novel as catharsis and spiritual reconciliation with the father, arguing that it "utilizes the epistemological and rudimentary nuances of the black church not only to prick the consciousness of America but also to challenge the subversive ideological dictates that consider African Americans 'unredeemable." 75 Brian Norman, who is one of the most prolific Baldwin scholars of this decade, reads Go Tell as "an explicitly political novel" and as "pretext for the successful emergence of the American Civil Rights movement."76 Baldwin, he argues, calls "for an embodied, non-duplicitous spirituality" not to "stand alone in righteousness," but "to transform the nation for the betterment of all."77 William J. Spurlin reads the novel in relationship to the Cold War discourse around homosexuality, the relationship between political and psychoanalytic constructions of homosexuality, and the later redeployment of these ideas in 1960s Black Nationalism. He finds that Baldwin's construction of gender in the novel challenges this discourse.

By mid-decade Baldwin studies found a very productive home in the advent of black queer studies. In Black Queer Studies: A Critical Anthology (2005), E. Patrick Johnson and Mae E. Henderson make the case for a "black queer studies" on the basis of exclusions created by black studies and queer studies, the former of which subordinated sexual identities and the latter of which subordinated racial identities. The editors applaud the deconstructive project of queer studies in theorizing identity, but also note the problems for people of color who "cannot afford to theorize their lives based on 'single variable' politics."78 Not surprisingly, such a critical project seems perfectly suited to the study of James Baldwin's writing. Baldwin, more than any other black writer of his time, crossed exclusionary identity lines and negotiated the challenging political implications of such crossings for people of color. These crossings made Baldwin an uncomfortable fit for theorists of black studies and queer studies and very arguably negatively impacted his legacy up until our own time. Dwight $\mathrm{A}$. McBride, who has done much to reinvigorate Baldwin studies-beginning with his 1999 book, James Baldwin Now-finds in Baldwin a "usable past" for this new critical project of black queer studies. 
In "Straight Black Studies: On African American Studies, James Baldwin, and Black Queer Studies," McBride tackles

a set of concerns about the related state of African American studies, the state of Baldwin scholarship, and the complicated relationship that Baldwin exhibits to identity politics and how that complexity presages the need for a critical sensibility ... this critical sensibility called black queer studies is self-consciously in search of a usable past to define and clarify the significance of its arrival on the scene in its current incarnation. ${ }^{79}$

McBride remarks on the lack of "sustained critical engagement" with the content of Baldwin's writing and argues that the emergence of cultural studies has made it possible to finally

understand Baldwin's vision of and for humanity in its complexity; locating him not as exclusively gay, black, expatriate, activist, or the like, but rather as an intricately negotiated amalgam of all of those things-an amalgam that had to be constantly tailored to fit the circumstances in which he was compelled to articulate himself. ${ }^{80}$

McBride goes on to describe some of that tailoring-like the elision of sexual identity-when Baldwin assumes the role of the "representative race man" and when others, like Amiri Baraka, incorporate Baldwin into the tradition of black cultural expression. McBride then analyzes Giovanni's Room as "not a novel about gay sexuality as much as it is about the social and discursive forces that make a 'problem' of gay sexuality," especially the way in which gay sexuality threatens the idea of home. ${ }^{81} \mathrm{He}$ concludes that Baldwin's work "reminds us that whenever we are speaking of race we are always already speaking about gender, sexuality and class." 82 For a further iteration of Baldwin's position in a tradition of queer African-American literature, one contextualized by analysis of Alain Locke's late reflections on how race respectability politics constrained the writing of the Harlem Renaissance, see Justin A. Joyce and Dwight A. McBride's essay in Douglas Field's Historical Guide to James Baldwin, "James Baldwin and Sexuality: Lieux de Memoire and a Usable Past."

Mae Henderson's essay, "James Baldwin's Giovanni's Room: Expatriation, 'Racial Drag, and Homosexual Panic"-also in Black Queer Studies-provides a close reading of the spatial and specular imagery in the novel in order to illuminate Baldwin's notion of identity. Explaining Baldwin's strategic use of white characters, she argues that "Baldwin's literary masquerade, and racial imposture, enables the author to examine internal aspects of the complex self by occupying a position of radical otherness" which she compares to the way Toni Morrison described Anglo-American writers serviceable deployment of black characters in Playing in the Dark. ${ }^{83}$ In another reversal of white literary practice, Henderson sees an ironic revision of the Jamesian theme of Americans in Europe; in Baldwin's novel it's the American who corrupts the European, not the other way around. Furthermore, 
for Baldwin "the expatriate becomes a trope for the homosexual who cannot reconcile his body and desire ... [the homosexual is] a stranger at home-a stranger unto himself." ${ }^{44}$ Henderson explores how spatial imagery and the reflective imagery of mirrors and water work together to create a potential for resolution in the novel, even though the fate of the main character, David, is uncertain. By the end Baldwin "conjoins notions of authenticity to complex subjectivity in order to open a space for the affirmation of self-difference-or the recognition of the otherness of the self." ${ }^{\prime 5}$ At the very conclusion of her essay, Henderson notes that Baldwin would cast off racial drag in his later work and go on to "explore black homosexuality as a theme and trope central to his vision of a reconstructed America and a reconstructed masculinity." 86 Yet, surprisingly, throughout the decade of Baldwin criticism being covered here, queer and black queer theorists have focused almost exclusively on Giovanni's Room and to a lesser extent on Go Tell and Another Country as well as the exchanges with Cleaver and Mailer and some late interviews and essays. Queer approaches have not led to a greater examination of Baldwin's later work, including Just Above My Head, Baldwin's most fully developed portrayal of a black gay man. Perhaps, though, it's not that surprising. Given the reliance of queer theory on deconstructive critical approaches, it may not offer a sufficient theoretical paradigm to investigate what Henderson rightly identifies as the reconstructive project of Baldwin's later fiction.

In “'Simply a Menaced Boy”: Analogizing Color, Undoing Dominance in James Baldwin's Giovanni's Room," Aliyyah I. Abur-Rahman builds on Mae Henderson's analysis of the novel's characters as performing in "racial drag," and discusses the novel's reception and its banishment from the black literary canon as a result of what McBride and others have described as "the policing of representations of racial blackness" and "censure of texts that are not overly political." ${ }^{7}$ However, Abur-Rahman does not assume that Baldwin believed that he had to transfigure race because of a rejection of homosexuality in African-American communities. Rather, Abur-Rahman emphasizes Baldwin's critique of whiteness, "specifically through his subtle allusions to the racializing effects of queerness." 88 She argues, persuasively, that "David's descent into intra-gender sexuality is simultaneously a descent into racial blackness" and that "Giovanni is the dark figure in the novel who serves as a repository for the longings and the anxieties of the white characters." ${ }^{99}$ She goes on to explore the link between sexual repression and sexual exploitation through David's family dynamics. Moreover, she disagrees with Yasmin DeGout's earlier critique of the novel that Baldwin sometimes represents homosexual desire as a failure of society, arguing rather that Baldwin represents exploitative homosexual behavior as not caused by homosexual desire but by the economic ordering of society. Guillaume is both a "sexual predator and a symbol of national manhood," and as such Baldwin uses him to indict a system that protects wealthy men and "the media and the mainstream public for their collusion."90 Abur-Rahman concludes that in Giovanni's Room, "Baldwin begins the imaginative project that would span his entire lifetime: that is, the dismantling of dominant theories of race, of masculinity, and of sexuality to reconceptualize 
and creatively reconstruct a more fundamentally egalitarian U.S." ${ }^{\prime 1}$ More than previous critics of Giovanni's Room, she reveals Baldwin's broader social critique and makes a very strong case for the centrality of this novel to Baldwin's oeuvre and thus to African-American literature.

Other articles that look at Baldwin's early fiction through a lens of queer theory include Mikko Tuhkanen's "Binding the Self: Baldwin, Freud, and the Narrative of Subjectivity" (2001), Matt Bell's "Black Ground Gay Figure: Working Through Another Country, Black Power and Gay Liberation” (2007), Michael Cobb's "Pulpitic Publicity: James Baldwin and the Queer Uses of Religious Words" (2001), Matt Brim's "Papa's Baby: Impossible Paternity in 'Going to Meet the Man"” (2006), and Kathryn Bond Stockton's Beautiful Bottom, Beautiful Shame: Where "Black" Meets "Queer" (2006). Mikko Tuhkanen's work draws on psychoanalytic theories of sexual development, Leo Bersani's The Culture of Redemption (1990), as well as Baldwin's own concern about the "protest novel," to examine the critical anxiety over Baldwin's supposedly compromised fictional narratives. Matt Bell also employs a psychoanalytic approach in his analysis of Another Country. He uses Freud's processes of "transference, repetition and working-through" to describe the characters' response to the death of Rufus and goes on to use these terms "to inform a reading of the historical narrative that joins black power and gay liberation." ${ }^{2}$ Foregrounding how the gay liberation movement used strategies of the Black Power movement, Bell concludes:

What Baldwin's novel and a Freudian approach to history invite us to see is that these apparently disparate historical moments are in fact moments in a shared history, that the discontinuities we might perceive ... merely mask the persistence of a structure that continues to delimit our perceptions of homosexuality and of blackness, both together and apart. ${ }^{93}$

Michael Cobb reads the authoritative religious language at the conclusion of Giovanni's Room and in the conversion scene of Go Tell It on the Mountain as a strategy through which queers make their prohibited feelings legible. He argues, "the queer exploits the pain and injury of normative narratives of belonging through a religious vernacular in order to have the privileges of publicity without having to reveal anything specific or 'really' painful about minority sexuality." ${ }^{4}$ For Cobb, "Baldwin's reliance on religion was entirely lexical," a strategy of "troubl[ing] history through religious rhetoric." "In his 2006 book, God Hates Fags: The Rhetorics of Religious Violence - the title of which comes from Reverend Fred Phelps's website-Cobb argues that queers today should follow Baldwin's lead in understanding that "hostile language often has a peculiar use value in oppositional politics." ${ }^{\prime 6}$ Religious hate speech works for queers because it allows them to make the "like race analogy," and Baldwin, he claims "understood the force of 'like race' politics perhaps like no other writer." ${ }^{\prime 7}$

Matt Brim's essay, indebted to Hortense Spiller's famous critique of gender and race relations as they were deformed by the African-American slave trade, 
examines the formations of "white" manhood in three stories in Baldwin's collection Going to Meet the Man. Brim claims that "The Rockpile," "The Man Child," and "Going to Meet the Man" are "interlocking texts ... bound together ... by their cumulative power to defamiliarize, to make strange, whiteness." ${ }^{98} \mathrm{He}$ argues that these texts are centered on anxieties about reproducing race and the white paternal order. The last story, "Going to Meet the Man," is key to interpreting the earlier ones in its explicit appropriation of black male bodies to expose a white man's paternal paranoia. He concludes that "reading Going to Meet the Man as a neo-passing narrative in which homo-productive interracial male union produces racially ambiguous sons, requires, suddenly, that we re-evaluate all 'white' children, tracing their parentage back to their multiple fathers as well as their mothers and fathers."99

Kathryn Bond Stockton's provocative and lyrical book exploring shame and debasement as a "switchpoint" between the signs "queer" and "black" includes a chapter on James Baldwin, Norman Mailer, and Eldridge Cleaver. Their readings and misreadings of each other have drawn the attention of previous critics, but Stockton's analysis is the most detailed-she considers both Soul on Ice and Giovanni's Room. Her fourth chapter, "Erotic Corpse: Homosexual Miscegenation and the Decomposition of Attraction," reads Baldwin's Giovanni's Room, Baldwin's "The White Boy Looks at the Black Boy," Mailer's “The White Negro," and Cleaver's Soul on Ice as they develop meanings around homosexual miscegenation. "Cleaver seeks to be freed from racial mixing and 'healed' from his participation in it ... [while Baldwin] attempts to occupy white men's minds in order to think attraction through their thoughts." 100 Of the three, only Mailer writes a "happy mix," although Cleaver is "ironically ... drawn to Mailer's happy attraction; Baldwin not at all." 101 At the center of this analysis is a decomposing corpse which exists in the depths of the mind. "Decomposition [Stockton argues] is Cleaver's and Baldwin's way of knowing the sad configuration of sexual relations in the wake of a desegregation that had not, by the time of their writings, and still never has, by the time of this study, actually come." 102 In Giovanni's Room Stockton finds a "Cleaver plot" in which homosexual miscegenation is produced by a flight from sexual sameness. ${ }^{103}$ Her close readings of David's intense attraction and repulsion to the dark Giovanni in Giovanni's Room are especially interesting; the image of the black man as a decomposing corpse in the white man's brain is a rebuttal to Mailer's assumption that white men could easily join in a black man's life. Yet Baldwin's white narrator, David, she claims, "has discovered his manhood, just as Cleaver himself would predict, in the bodies of dark men. This is a manhood against expectations. It knows the sorrow of holding a man, beholding a man, who decomposes in other men's minds." 104

Clarence E. Hardy III's James Baldwin's God: Sex, Hope, and Crisis in Black Holiness Culture (2003) is the first full-length study of what Baldwin's biographer, David Leeming, called the "knotty question" of Baldwin's relationship to religion. ${ }^{105}$ Hardy, a theologian and professor of religion, shared Baldwin's struggle with black holiness culture and offers an inside perspective on Baldwin's deep 
ambivalence regarding that religious tradition. His book, organized thematically, draws widely from Baldwin's oeuvre, but foregrounds Go Tell It on the Mountain and The Fire Next Time. Hardy reviews Baldwin's well-known charges against the Christian Church-its central role in the support of American chattel slavery, its denial of the flesh, its implication in the psychology of black self-hatred and white supremacy_noting that Baldwin's arguments are in line with contemporary black liberationist theologians. In The Fire Next Time, Baldwin explicitly rejects not only the hypocritical Christian Church, but also the notion of a supernatural God existing outside the human imagination. Yet, as Hardy argues, Baldwin continued to "offer a prophetic vision for the church," calling people both "inside and outside of religious communities to account." ${ }^{106}$ More than previous Baldwin scholars, Hardy suggests that Baldwin was not only embedded in, but to some extent compromised by the tradition he rejected. What becomes clear in Hardy's analysis is that Baldwin's connection to black holiness culture is not just rhetorical. Nor is it only a connection to the musical tradition, although Baldwin at various points associates music with "the true religion," and as Hardy notes, music sanctifies religion for Baldwin rather than the other way around. ${ }^{107}$ Hardy is not uncritical of Baldwin. Rather, it is Baldwin's vision of redemption and suffering that ties him somewhat problematically to the evangelical tradition of his youth. Hardy writes,

Like his father, Baldwin sees hope for a righteous few in the ultimate damnation of those (white elites) who have demonstrated their moral inferiority through their own acts of brutality. He embraces the strategies of a religious perspective he seemingly rejects as he envisages suffering as the key in the development of black people's gift to the United States and to humanity... ${ }^{108}$

Similarly, Hardy senses an ambivalence in Baldwin's celebration of love and physical intimacy in his novels, as well as in his discussions about his own sexuality, that suggest "how ingrained Christianity's rejection of the body truly is in black religion." ${ }^{109}$ Descriptions of even the most loving sexual relations in the later novels are often imbued with mystery, strangeness, and alienation. ${ }^{110}$ Drawing on Baldwin's conversations with Nikki Giovanni and Audre Lorde, Hardy exposes the sexism in Baldwin's analysis of white supremacy. ${ }^{111}$ Hardy also finds Baldwin's use of "bastard" as a metaphor for black life in America and his fixation on the missing father as deeply problematic. While this metaphor reveals "the psychosexual dimensions of white supremacy," it elides an economic critique of American society, "suggests the extent to which he is obsessed with gaining recognition from whites," and "breeds a silent and poisonous sexism." 12 Hardy concludes with a poignant reflection on the claim, often made by Baldwin, that blacks have a unique relationship to American society, noting that this closeness of blacks to an American identity "bespeaks of a tragedy at least as much as it hints at promise and hope." 113

Douglas Field is also interested in the Black Pentecostal roots of Baldwin's religion, but while Hardy explores the ambivalence of that tradition in Baldwin's 
writing, Field is more interested in its productive aspects for Baldwin's developing notion of spirituality. In "Pentecostalism and All That Jazz: Tracing James Baldwin's Religion," Field addresses the "critical silence surround[ing] the question of whether [Baldwin] was a religious writer or not." 114 Field takes on a near consensus among literary and cultural critics who see Baldwin's use of religious language as "simply a matter of style" and who see "a progressive secularization in Baldwin's work." 115 Field, on the other hand, sees Baldwin moving toward a religious notion of transcendence outside the Church that is best represented in the later novels' depictions of the power of black music and of spiritual sexual love. Citing Baldwin's essay, "The Use of the Blues," Field notes that Baldwin's commentary "makes it clear that music is not so much a substitute for religion, but that music is itself a spiritual medium that has the ability to reach out to others."116 Field's detailed exploration of the break between mainstream Christian churches and Pentecostalism is of particular interest. He makes a good case that Baldwin's vision of transcendence and his emphasis on personal salvation come out of the anti-establishment, anti-clerical, exilic, and Africanist musical elements of Pentecostalism, a religion that encouraged the participation of women and children, gave voice to untrained preachers, and most significantly offered an ecstatic unmediated experience of God. In line with the antinomian impulse of this "old time religion," Baldwin insists on a personal embodied connection with others that provides at least momentary transcendence from one's suffering existence. Exploring Baldwin's "developing notion of love as key to understanding" Baldwin's life and work, Field concludes that "love, then, aided and nurtured through gospel music becomes the bedrock of Baldwin's new religion." 117

James Baldwin's relationship to Harlem and to Harlem-based, mostly black writers, intellectuals, and political activists is the subject of writer and journalist Herb Boyd's Baldwin's Harlem: A Biography of James Baldwin (2008). Boyd, concerned that Baldwin had not been sufficiently honored in his city of origin, sets out to defend Baldwin from "those writers and critics who seemed to relish bashing him." 118 Boyd explores Baldwin's contentious (but not always bashing) relationships with Langston Hughes, Ralph Ellison, Malcolm X, Amiri Baraka, Stanley Crouch, and Harold Cruise, as well as his activism in the Harlem Six case and his relationship with and characterization of Jews in New York. Among the relationships with black luminaries that Boyd recounts, only that with Countee Cullen, one of Baldwin's teachers, occurred when Baldwin was actually living in Harlem. As Baldwin made clear in his writing, the Harlem he grew up in was not the Harlem of Sugar Hill or the world of the Harlem Renaissance. As Michel Thelwell aptly puts it in an interview at the end of the book, "what many people fail to understand is that Jimmy was in but not of Harlem."119 Baldwin had to leave his impoverished and narrowly religious environment to develop his talent, while Ellison and Hughes came to the mecca of black culture to develop theirs. Albert Murray criticized Baldwin for never praising the cultural wealth of Harlem, which Boyd tries to counter in a rather cursory chapter on Baldwin's literary representations of the city. However, Boyd seems to mostly provide evidence for 
Murray's claim. With some limited exceptions to be found in the last two novels, Harlem is mostly "depicted as squalid, an absolutely dreadful place to live," as an "irrepressible ghetto" or simply "alluded to . . . or taken for granted." ${ }^{20}$ Boyd recounts how Baldwin's depictions, particularly of the housing projects, angered more prosperous Harlem residents. Boyd's conclusion that Harlem was Baldwin's "spiritual home" seems a bit sentimental. It certainly was the home he came from and that he revisits in life and imagination, but Baldwin's homes were many.

Not the least of which was Istanbul. The renewed interest in James Baldwin, especially in his lesser known texts and his life after the early 1960s, is most fully realized in Magdalena Zaborowska's groundbreaking 2009 work, James Baldwin's Turkish Decade: Erotics of Exile. Zaborowska makes a powerful case for the importance of Turkey to Baldwin's development as a "black queer writer, one who was ahead of rather than behind his time." ${ }^{21}$ Based in part on personal interviews with Baldwin's good friends, acquaintances, and collaborators in Turkey, as well as on numerous Turkish sources including letters, memoirs, and reviews, plus previously unseen gorgeous photographs, her book brings a wealth of new primary source material to Baldwin studies. Throughout, Zaborowska is always alert to how Baldwin's sexuality is or isn't represented, and the possible significance of silence and deflection. As Zaborowska goes looking for Baldwin in Turkey, she occasionally writes herself into her text. This intimacy is uncommon in scholarly books, but entirely appropriate for writing about James Baldwin, a writer whose intimate voice is at the center of his continued appeal. What she finds as she probes Baldwin himself probing the links between race and sex in American identity is that Turkey provided a "free space," a "nurturing authorial lair" where Baldwin could "exorcise and embrace his traumatizing material from a safe distance."122 She writes,

Its openness and, at times, boldness reflect the freedom from public scrutiny and condemnation that Baldwin felt in Istanbul as a queer. As Oktay Balamir [Baldwin's friend and the translator of Fortune and Men's Eyes] said in our interview, "This may sound surprising to you, but Jim's homosexuality was never apparent in Turkey. None of the Turks took him as a 'gay writer.' He met all the top authors of Turkey, including Yasur Kemal . . . People just knew but didn't care about lit . . It was just a marginal issue. ${ }^{123}$

Not only did Turkey offer a safe space for Baldwin's developing ideas on "identity, desire and representation," not widely recognized among his American readers, but his work was and continues to be well received in Turkey. ${ }^{124}$

Using a mix of cultural, queer, feminist, and architectonic theory, Zaborowska provides original, well-developed, close readings of Another Country and No Name in the Street as well as a detailed discussion of the controversial Canadian play, Fortune and Men's Eyes, translated into Turkish, which Baldwin directed in Istanbul at Engin Cezzar's theater. Zaborowska argues that Turkey made it possible for Baldwin to "question American binary constructions of race and sexuality and to arrive at an articulation of what we would today call a queer identity," which is 
first evident in his third novel, Another Country, where she finds both implicit and explicit Turkish references. ${ }^{125}$ Of particular interest is her discussion of Baldwin's strategic use of Orientalism through his characters' perspectives. Vivaldo, in particular, is revealed as less sympathetic than others have read him to be. We are left with a greater appreciation for this novel's challenging critique of race and sex than more sentimental readings have delivered. The play, Fortune and Men's Eyes, translated as Dusenin Dostu, barely avoided being banned, but was a major success in Istanbul, running for over 100 performances. About prison violence, homosexual panic, and masculinity, the play, Zaborowska argues, became important to Baldwin's later work, especially to No Name in the Street. Zaborowska does much to rehabilitate this misunderstood text. Finding a deliberate pattern in a book many of its readers found confusing, No Name, she argues, "should be read as one of the key accounts of the national psychosexual and racial drama at the heart of the historical moment." 126

As suggested by Claudia Roth Pierpont's 2009 New Yorker essay, "Another Country: James Baldwin's Flight from America"-a biographical piece, which includes a review of Zaborowska's book-the popular narrative of Baldwin's "decline" and its causes was starting to be questioned at the end of the decade by at least some of the literati, thanks to a new generation of Baldwin scholars. Although Pierpont rehearses the arguments for Baldwin's decline, she seems persuaded by Zaborowska's recovery of No Name in the Street as an important experimental text, and she responds to the old charge that Baldwin had exchanged art for politics by asking, "But isn't it as likely that Baldwin's dedication to the movement, starting back in the late fifties, allowed him to accomplish as much as he did?"127 The first decade of the new millennium saw a renewal of Baldwin scholarship. New critical approaches-and some historical distance-provided scholars with the tools to better appreciate the complexity and depth of Baldwin's oeuvre, including his later and lesser known texts, his art, and his messages to the nation and to individuals.

\section{Notes}

1 For example, a quick search by author's name of the Modern Language Association Bibliography indicates there are roughly a third more entries on Richard Wright than on James Baldwin during the decade.

2 Pen American Center, “Tribute to James Baldwin: Entire Event," https://soundcloud. com/penamerican/tribute-to-james-baldwin (accessed 8 September 2016).

3 “James Baldwin's Grand Tour," Pen America: A Journal for Writers and Readers, 1:2 (2001), pp. 17-54. The article includes tributes by Thulani Davis, Carl Hancock Rux, David Leeming, Hilton Als, Nikki Giovanni, Russell Banks, Amiri Baraka, Eleanor Traylor, John Edgar Wideman, Chinua Achebe, and a reprint of Baldwin's "Stranger in the Village."

4 Quentin D. Miller, "Proceedings from the Conference 'James Baldwin: In His Time/ In Our Time," Obsidian III: Literature in the African Diaspora, 9:2 (2008), pp. 8-11. Miller celebrates a new willingness to engage in all of Baldwin's work, the rigorous use of new critical lenses, and a new generation of Baldwin scholars bringing fresh perspectives 
to his work. The essays in this special issue include two comparative treatments of Baldwin and his contemporaries: Another Country read alongside William Gardner Smith's Last of the Conquerors, and Blues for Mister Charlie read alongside Lorraine Hansberry's Raisin in the Sun; a reading of Baldwin's short story collection, Going to Meet the Man, as a unified text; and essays on Tell Me How Long the Train's Been Gone and Just Above My Head (both mentioned later in this essay).

5 Edited book collections include Carol E. Henderson's James Baldwin's Go Tell It on the Mountain: Historical and Critical Essays (Peter Lang, 2006), discussed later in this essay; James Baldwin and Toni Morrison: Comparative Critical and Theoretical Essays (Palgrave Macmillan, 2006), edited by Lovalerie King and myself; and A Historical Guide to James Baldwin (Oxford University Press, 2009), edited by Douglas Field. King's and my book includes thirteen essays by established and younger scholars. Inspired by Morrison's eulogy, which credited Baldwin's outsized influence on representing race in American letters, the editors examine the dialogic relationship between these writers in order to bring new critical insights to their work that has been mostly read through rather different critical lenses. Essays in this volume look at questions of narrative construction, subject position, legal discourse, themes of love, incest, constructions of whiteness, uses of music, the figure of the preacher and of the "bad man," Stagolee, and other topics, including the limitations of their representations of homosexuality and gender. Revision is a prominent theme of several essays, both as Morrison and Baldwin appear to revise each other, as well as their work together, in similar and different ways, to revise oppressive cultural scripts. Field's book, a collection of essays by seasoned Baldwin scholars, successfully brings together many of the central issues in Baldwin studies. Field emphasizes the dynamic, changing nature of Baldwin's role as artist, political spokesperson and celebrity. The collection is organized by topic-religion, music, sexuality, politics, and transnational connections-resisting earlier tendencies to divide Baldwin's work by genre or by a before/after narrative. The collection also includes a new biographical essay, a bibliography and chronology.

6 Randall Kenan, "Introduction: Looking for James Baldwin," in James Baldwin, The Cross of Redemption: Uncollected Writings, ed. Randall Kenan (New York, Pantheon, 2010), p.xv.

7 James Baldwin, “To Crush a Serpent," in Kenan (ed.), The Cross of Redemption, pp. 161, 164.

8 Ibid., p. 165.

9 Lawrie Balfour, The Evidence of Things Not Said: James Baldwin and the Promise of American Democracy (Ithaca, N.Y., Cornell University Press, 2001), pp. 6, xii.

10 Ibid., p. 31.

11 Ibid., p. 27.

12 George Shulman, American Prophecy: Race and Redemption in American Political Culture (Minneapolis, MN, University of Minnesota Press, 2008), p. 24.

13 Ibid., pp.93-4.

14 Ibid., pp. 169, 170.

15 Carol Polsgrove, Divided Minds: Intellectuals and the Civil Rights Movement (New York, W.W. Norton, 2001), p. 185.

16 Will Walker, "After the Fire Next Time: James Baldwin's Postconsensus Double Bind," in Eddie S. Glaude, Jr. (ed.), Is It Nation Time? (Chicago, University of Chicago Press, 2002), p. 217. 
17 Ibid., p. 216.

18 Ibid., p. 220.

19 Ibid., pp.221-2. According to Walker, Baldwin shared the Nationalists' critique of black victimhood as constitutive of American identity, but didn't share their view of culture. Consistent throughout Baldwin's work is his commitment to racial and cultural hybridity and a view of African-American culture as uniquely American, coming out of black historical experience in resisting slavery and oppression.

20 Bill Lyne, “God's Black Revolutionary Mouth': James Baldwin's Radicalism," Science \& Society, 74:1 (2010), p. 14.

21 Ibid., p. 17.

22 See Henry Louis Gates, Jr., "What James Baldwin Can and Can't Teach America," New Republic, 1 June 1992, p. 42, where he states, “Desperate to be 'one of us', to be loved by his own, Baldwin allowed himself to mouth a script that was not his own. The connoisseur of complexity tried his hand at being an ideologue. To be sure, he could still do anything he wanted with the English essay. The problem was that he no longer knew quite what he wanted, and he cared too much about what others wanted from him."

23 Brian Norman, The American Protest Essay and National Belonging: Addressing Division (Albany, N.Y., State University of New York Press, 2007), p. 2.

24 Ibid., pp. 88, 89.

25 Ibid., p. 96. Brian Norman is the author of several important articles on Baldwin over the decade; three not covered in this essay are "Crossing Identitarian Lines: Women's Liberation and James Baldwin's Early Essays,” Women's Studies, 35:3 (2006), pp. 241-64; "Reading a 'Closet Screen Play': Hollywood, James Baldwin's Malcolms and the Threat of Historical Irrelevance," African American Review, 39:1-2 (2005), pp. 103-18; and "James Baldwin's Unifying Polemic: Racial Segregation, Moral Integration and the Polarizing Figure of Emmett Till," in Harriet Pollack and Christopher Metress (eds.), Emmett Till in Literary Memory and Imagination (Baton Rouge, LA, Louisiana State University Press, 2008), pp.75-97.

26 Richard Schur, “Unseen or Unspeakable? Racial Evidence in Baldwin's and Morrison's Nonfiction," in Lovalerie King and Lynn Orilla Scott (eds.), James Baldwin and Toni Morrison: Comparative Critical and Theoretical Essays (New York, Palgrave Macmillan, 2006), pp. 206, 207.

27 Ibid., p. 218.

28 Deak Nabers, "Past Using: James Baldwin and Civil Rights Law in the 1960s," Yale Journal of Criticism: Interpretation in the Humanities, 18:2 (2005), p. 233.

29 Ibid., p. 240.

30 Ibid., p. 240.

31 Ibid., p. 241.

32 F. W. Dupee, for example, wanted Baldwin to put his assertions to a "pragmatic test" and Langston Hughes also questioned Baldwin's lack of solutions to the race problem. See my essay "Challenging the American Conscience, Re-Imagining American Identity: James Baldwin and the Civil Rights Movement," in Douglas Field (ed.), $A$ Historical Guide to James Baldwin (Oxford, Oxford University Press, 2009), pp. 156-7.

33 Quentin D. Miller, “The Fire Next Time and the Law," in Lovalerie King and Richard Schur (eds.), African American Culture and Legal Discourse (New York, Palgrave Macmillan, 2009), pp. 126-7.

34 Ibid., p. 128. 
35 Lynn Orilla Scott, James Baldwin's Later Fiction: Witness to the Journey (East Lansing, MI, Michigan State University Press, 2002), p. 10.

36 See Houston A. Baker, Jr., "The Embattled Craftsman: An Essay on James Baldwin," in Fred L. Standley and Nancy V. Burt (eds.), Critical Essays on James Baldwin (Boston, MA, G.K. Hall, 1988), pp. 62-77.

37 See Eleanor Traylor, "I Hear Music in the Air: James Baldwin's Just Above My Head," in Quincy Troupe (ed.), James Baldwin: The Legacy (New York, Touchstone-Simon and Schuster, 1989), pp. 95-106.

38 Quentin D. Miller (ed.), Reviewing James Baldwin: Things Not Seen (Philadelphia, PA, Temple University Press), p. 2; Douglas Field, "Looking for Jimmy Baldwin: Sex, Privacy, and Black Nationalist Fervor," Callaloo: A Journal of African-American and African Arts and Letters, 27:2 (2004), p. 465. Field speculates that Baldwin's representation of homosexuality was constrained by the homophobic attacks and dismissals that Baldwin experienced, particularly in his role as a movement spokesperson. The essay thoroughly documents the homophobic climate of much of the Black Nationalist movement, while confirming Baldwin's genuine support of Black Power and the Panthers. It would appear that the influence went both ways and that the "Black Power Movement was indebted to [Baldwin's] rhetoric as well" (ibid., p. 468). However, Field's claim that Cleaver and others had a devastatingly negative impact on Baldwin's later work relies on the mostly negative contemporary reviews of that work, rather than on new analysis.

39 Keith Clark, Black Manhood in James Baldwin, Ernest Gaines, and August Wilson (Urbana, IL, Illinois University Press, 2002), p. 33.

40 Ibid., p. 48.

41 Ibid., p. 51.

42 Ibid., pp. 52, 54.

43 Ibid., p. 56.

44 Ibid., p.58. For this line of criticism, see also Melvin Dixon, Ride Out the Wilderness: Geography and Identity in Afro-American Literature (Urbana and Chicago, University of Illinois Press, 1987), pp. 134-40.

45 Ibid., p. 60.

46 Rolland Murray, Our Living Manhood: Literature, Black Power and Masculine Ideology (Philadelphia, PA, University of Pennsylvania Press, 2007), p. 3.

47 Ibid., p. 9.

48 Ibid., p. 36.

49 Ibid., p. 15.

50 See Field, "Looking for Jimmy Baldwin," for a similar, but earlier analysis of Baldwin's response to Cleaver.

51 Murray, Our Living Manhood, p. 32.

52 Clark, Black Manhood, p. 58.

53 Ibid., p. 58.

54 Murray, Our Living Manhood, p. 27.

55 Robert Reid-Pharr, Once You Go Black: Choice, Desire, and the Black American Intellectual (New York, New York University Press, 2007), p. 6.

56 Ibid., p. 18.

57 Ibid., pp.7-8.

58 Ibid., p. 14.

59 Ibid., p. 33. 
60 Ibid., p. 100.

61 Ibid., p. 101.

62 Ibid., p. 104.

63 Ibid., p. 108.

64 Ibid., p. 115.

65 Ibid., p. 118.

66 Brian Norman, "James Baldwin's Confrontation with US Imperialism in If Beale Street Could Talk," MELUS, 32:1 (2007), p. 121.

67 Ibid., p. 124.

68 Ibid., pp. 125, 132.

69 Aaron Oforlea, "Remaking and Marking Tradition: Black Male Subjectivity in Baldwin's Tell Me How Long the Train's Been Gone," Obsidian III: Literature in the African Diaspora, 9:2 (2008), p.71.

70 Pekka Kilpelainen, "Transcending the Boundaries of Race and Sexuality: James Baldwin's Vision of Postcategorical Utopia," in Jopi Nyman (ed.), Post-National Enquiries: Essays on Ethnic and Racial Border Crossings (Newcastle upon Tyne, Cambridge Scholars, 2009), p. 50.

71 Ibid., p. 59.

72 Joanna Jeskova, "Incestuous Violence and Brotherly Love in James Baldwin's Just Above My Head," Obisdian III: Literature in the African Diaspora, 9:2 (2008), p. 87.

73 Lynn Orilla Scott, "Revising the Incest Story: Toni Morrison's Bluest Eye and James Baldwin's Just Above My Head," in King and Scott (eds.), James Baldwin and Toni Morrison, p. 98.

74 These essays plus additional ones were reprinted in Carol E. Henderson (ed.), James Baldwin's Go Tell It on the Mountain: Historical and Critical Essays (New York, Peter Lang, 2006).

75 Carol E. Henderson, "Reconciling the Spirit of the Father: James Baldwin's Go Tell It on the Mountain 50 Years Later," MAWA Review, 19:1 (2004), p.7.

76 Brian Norman, "Duplicity, Purity, and Politicized Morality: Go Tell It on the Mountain and the Emergence of the Civil Rights Movement," MAWA Review, 19:1 (2004), p. 105.

77 Ibid., p. 117.

78 E. Patrick Johnson and Mae G. Henderson (eds.), Black Queer Studies: A Critical Anthology (Durham, N.C., Duke University Press, 2005), p. 5.

79 Dwight A. McBride, "Straight Black Studies: On African American Studies, James Baldwin, and Black Queer Studies," in Johnson and Henderson (eds.), Black Queer Studies, p. 71.

80 Ibid., p. 75.

81 Ibid., p. 79.

82 Ibid., pp. 86-7.

83 Mae G. Henderson, “James Baldwin's Giovanni's Room, 'Racial Drag,' and Homosexual Panic," in Johnson and Henderson (eds.), Black Queer Studies, p. 300.

84 Ibid., p. 313.

85 Ibid., p. 319.

86 Ibid., p. 320.

87 Aliyyah I. Abur-Rahman, “Simply a Menaced Boy': Analogizing Color, Undoing Dominance in James Baldwin's Giovanni's Room," African American Review, 41:3 (2007), p. 478. 
88 Ibid., p. 480.

89 Ibid., pp. 481, 482.

90 Ibid., p. 484.

91 Ibid., p. 485.

92 Matt Bell, "Black Ground Gay Figure: Working Through Another Country, Black Power and Gay Liberation," American Literature: A Journal of Literary History, Criticism, and Bibliography, 79:3 (2007), p. 578.

93 Ibid., p. 599.

94 Michael Cobb, "Pulpitic Publicity: James Baldwin and the Queer Uses of Religious Words," GLQ: A Journal of Lesbian and Gay Studies, 7:2 (2001), p. 257.

95 Ibid., p. 290.

96 The source for Cobb's title comes from God Hates Fags: Westboro Baptist Church Home Page, 1 May 2016, http://www.godhatesfags.com (accessed 8 September 2016). Michael Cobb, God Hates Fags: The Rhetorics of Religious Violence (New York, New York University Press, 2006), p. 9.

97 Ibid., p. 16.

98 Matt Brim, “Papa's Baby: Impossible Paternity in 'Going to Meet the Man,” Journal of Modern Literature, 30:1 (2006), p. 173.

99 Ibid., p. 196.

100 Kathryn Bond Stockton, Beautiful Bottom, Beautiful Shame: Where "Black" Meets “Queer" (Durham, N.C., Duke University Press, 2006), p. 153.

101 Ibid., p. 154.

102 Ibid., p. 154.

103 Ibid., p. 168.

104 Ibid., p. 176.

105 See the interview with David Leeming in Karen Thorsen's documentary. Karen Thorsen et al., James Baldwin: The Price of the Ticket (San Francisco, California Newsreel, 1989), Electronic Resource, Michigan State University.

106 Clarence E. Hardy III, James Baldwin's God: Sex, Hope, and Crisis in Black Holiness Culture (Knoxville, TN, University of Tennessee Press, 2003), p. 13.

107 Ibid., p. 58.

108 Ibid., p. 50.

109 Ibid., p. 68.

110 Ibid., pp. 66-7.

111 Ibid., p.70.

112 Ibid., pp. 104, 105.

113 Ibid., p.112. In a later essay Hardy argues that Baldwin's Church experience taught him "just how intertwined Christianity was with social power in the United States." Hardy concludes that, just as Baldwin was in exile from his country, yet still "the most peculiarly American of authors," he was in exile from the Church he had served, yet "revealed himself to be the most peculiarly religious of black writers in the postwar era." From "James Baldwin as a Religious Writer: Burdens and Gift of Black Evangelicalism," in Field (ed.), A Historical Guide to James Baldwin, pp. 63, 79.

114 Douglas Field, "Pentecostalism and All That Jazz: Tracing James Baldwin's Religion," Literature and Theology: An International Journal of Religion, Theory, and Culture, 22:4 (2008), p. 438.

115 Ibid., pp. 437, 438. 
116 Ibid., p. 449.

117 Ibid., pp. 450, 453.

118 Herb Boyd, Baldwin's Harlem: A Biography of James Baldwin (New York, Simon and Schuster, 2008), pp.xxiii-xiv. In 2015, after Boyd's book was published, a street in Harlem was named James Baldwin Way.

119 Ibid., p. 191.

120 Ibid., pp. 127, 128.

121 Magdalena J. Zaborowska, James Baldwin's Turkish Decade: Erotic of Exile (Durham, N.C., Duke University Press, 2009), p. 251.

122 Ibid., p. 218.

123 Ibid., p. 218.

124 Ibid., p. 251. Tell Me How Long the Train's Been Gone was warmly received in Turkey in contrast to the largely negative reviews in the United States.

125 Ibid., p. 102.

126 Ibid., p.221. Two additional articles written during this decade by Zaborowska focus on Baldwin's earlier work. She views Baldwin's complex notions of identity through "the interdisciplinary lens of immigrant studies" in "Racing Transatlantic Passages: James Baldwin's African 'America' and Immigrant Studies," in Ramaswami Mahalingam (ed.), Cultural Psychology of Immigrants (Mahwah, N.J., Lawrence Erlbaum, 2006), p. 170. She analyzes Baldwin's use of immigrant narrative motifs and his "migratory, and heterotopic model of ... American identity" in "In the Same Boat': James Baldwin and the Other Atlantic," in Field (ed.), A Historical Guide to James Baldwin, pp. 181-2.

127 Claudia Roth Pierpont, "Another Country: James Baldwin's Flight from America," The New Yorker, 9 February 2009, par. 24, http://www.newyorker.com/magazine/2009/02/09/another-country (accessed 27 June 2016).

\section{Works Cited}

Abur-Rahman, Aliyyah I., "Simply a Menaced Boy': Analogizing Color, Undoing Dominance in James Baldwin's Giovanni's Room," African American Review, 41:3 (2007), pp. 477-86.

Baker, Houston A., Jr., “The Embattled Craftsman: An Essay on James Baldwin," in Fred L. Standley and Nancy V. Burt (eds.), Critical Essays on James Baldwin (Boston, MA, G.K. Hall, 1988), pp. 62-77.

Baldwin, James, The Cross of Redemption: Uncollected Writings, ed. Randall Kenan (New York, Pantheon, 2010).

Baldwin, James, and Engin Cezzar, Dost Mektuplari, trans. Seckin Selvi (Istanbul, YKY, 2007).

Baldwin, James, and Sol Stein, Native Sons: A Friendship That Created One of the Greatest Works of the Twentieth Century: Notes of a Native Son (New York, One World/Ballantine Books, 2004).

Balfour, Lawrie, The Evidence of Things Not Said: James Baldwin and the Promise of American Democracy (Ithaca, N.Y., Cornell University Press, 2001).

Bell, Matt, "Black Ground Gay Figure: Working Through Another Country, Black Power and Gay Liberation," American Literature: A Journal of Literary History, Criticism, and Bibliography, 79:3 (2007), pp. 577-603. 
Boyd, Herb, Baldwin's Harlem: A Biography of James Baldwin (New York, Simon and Schuster, 2008).

Brim, Matt, "Papa's Baby: Impossible Paternity in 'Going to Meet the Man," Journal of Modern Literature, 30:1 (2006), pp. 173-98.

Clark, Keith, Black Manhood in James Baldwin, Ernest J. Gaines, and August Wilson (Urbana, IL, Illinois University Press, 2002).

Cobb, Michael, God Hates Fags: The Rhetorics of Religious Violence (New York, New York University Press, 2006).

— "Pulpitic Publicity: James Baldwin and the Queer Uses of Religious Words," GLQ: A Journal of Lesbian and Gay Studies, 7:2 (2001), pp. 285-308.

Davis, Thulani, et al., "James Baldwin's Grand Tour," Pen America: A Journal for Writers and Readers, 1:2 (2001), pp. 17-42.

Dixon, Melvin, Ride Out the Wilderness: Geography and Identity in Afro-American Literature (Urbana and Chicago, University of Illinois Press, 1987).

Field, Douglas (ed.), A Historical Guide to James Baldwin (Oxford, Oxford University Press, 2009).

"Looking for Jimmy Baldwin: Sex, Privacy and Black Nationalist Fervor," Callaloo: A Journal of African-American and African Arts and Letters, 27:2 (2004), pp.457-80.

"Pentecostalism and All That Jazz: Tracing James Baldwin's Religion," Literature \& Theology: An International Journal of Religion, Theory, and Culture, 22:4 (2008), pp. 436-57.

Gates, Jr., Henry Louis, "What James Baldwin Can and Can't Teach America," New Republic, 1 June 1992.

Hardy, Clarence E., III., "James Baldwin as a Religious Writer: Burdens and Gifts of Black Evangelicalism," in Douglas Field (ed.), A Historical Guide to James Baldwin (Oxford, Oxford University Press, 2009), pp. 233-52.

_ James Baldwin's God: Sex, Hope, and Crisis in Black Holiness Culture (Knoxville, TN, University of Tennessee Press, 2003).

Henderson, Carol E. (ed.), James Baldwin's Go Tell It on the Mountain: Historical and Critical Essays (New York, Peter Lang, 2006).

"Reconciling the Spirit of the Father: James Baldwin's Go Tell It on the Mountain 50 Years Later," MAWA Review, 19:1 (2004), pp.3-10.

Henderson, Mae G., “James Baldwin's Giovanni’s Room, 'Racial Drag,' and Homosexual Panic," in E. Patrick Johnson and Mae G. Henderson (eds.), Black Queer Studies: A Critical Anthology (Durham, N.C., Duke University Press, 2005), pp. 298-322.

Jeskova, Joanna, “Incestuous Violence and Brotherly Love in James Baldwin's Just Above My Head," Obsidian III: Literature in the African Diaspora, 9:2 (2008), pp.77-88.

Johnson, E. Patrick, and Mae G. Henderson (eds.), Black Queer Studies: A Critical Anthology (Durham, N.C., Duke University Press, 2005).

Joseph, Peniel E., Waiting 'Til the Midnight Hour: A Narrative History of Black Power in America (New York, Henry Holt, 2006).

Joyce, Justin A., and Dwight A. McBride, "James Baldwin and Sexuality: Lieux de Memoire and a Usable Past," in Douglas Field (ed.), A Historical Guide to James Baldwin (Oxford, Oxford University Press, 2009), pp. 111-39.

Kilpelainen, Pekka, “Transcending the Boundaries of Race and Sexuality: James Baldwin's Vision of Postcategorical Utopia," in Jopi Nyman (ed.), Post-National Enquiries: Essays on Ethnic and Racial Border Crossings (Newcastle upon Tyne, Cambridge Scholars, 2009), pp. 47-61. 
King, Lovalerie, and Lynn Orilla Scott (eds.), James Baldwin and Toni Morrison: Comparative Critical and Theoretical Essays (New York, Palgrave Macmillan, 2006).

Lyne, Bill, "God's Black Revolutionary Mouth: James Baldwin's Radicalism," Science \& Society, 74:1 (2010), pp. 12-36.

McBride, Dwight A. (ed.), James Baldwin Now (New York, New York University Press, 1999).

_ "Straight Black Studies: On African American Studies, James Baldwin, and Black Queer Studies," in E. Patrick Johnson and Mae G. Henderson (eds.), Black Queer Studies: A Critical Anthology (Durham, N.C., Duke University Press, 2005), pp.68-89.

Miller, D. Quentin, "The Fire Next Time and the Law," in Lovalerie King and Richard Shut (eds.), African American Culture and Legal Discourse (New York, Palgrave Macmillan, 2009), pp. 117-30.

_ "Proceedings from the Conference 'James Baldwin: In His Time/In Our Time," Obsidian III: Literature in the African Diaspora, 9:2 (2008), pp. 8-11.

- (ed.), Re-Viewing James Baldwin: Things Not Seen (Philadelphia, PA, Temple University Press, 2000).

Murray, Rolland, Our Living Manhood: Literature, Black Power and Masculine Ideology (Philadelphia, PA, University of Pennsylvania Press, 2007).

Nabers, Deak, "Past Using: James Baldwin and Civil Rights Law in the 1960s," Yale Journal of Criticism: Interpretation in the Humanities, 18:2 (2005), pp. 221-42.

Norman, Brian, The American Protest Essay and National Belonging: Addressing Division (Albany, N.Y., State University of New York Press, 2007).

_ “Crossing Identitarian Lines: Women's Liberation and James Baldwin's Early Essays," Women's Studies: An Interdisciplinary Journal, 35:3 (2006), pp. 241-64.

_Duplicity, Purity, and Politicized Morality: Go To Tell It on the Mountain and the Emergence of the Civil Rights Movement," MAWA Review, 19:1 (2004), pp. 105-20.

_ “James Baldwin's Confrontation with U.S. Imperialism in If Beale Street Could Talk," MELUS, 32:1 (2007), pp. 119-38.

_James Baldwin's Unifying Polemic: Racial Segregation, Moral Integration, and the Polarizing Figure of Emmett Till," in Harriet Pollack and Christopher Metress (eds.), Emmett Till in Literary Memory and Imagination (Baton Rouge, LA, Louisiana State University Press, 2008), pp. 75-97.

_ "Reading a 'Closet Screenplay': Hollywood, James Baldwin's Malcolms and the Threat of Historical Irrelevance," African American Review, 39:1-2 (2005), pp. 103-18.

Norman, Brian, and Lauren A. Wilson, "A Historical Guide to James Baldwin (review)," Callaloo: A Journal of African Diaspora Arts and Letters, 33:4 (2010), pp. 1145-48.

Oforlea, Aaron, "Remaking and Marking Tradition: Black Male Subjectivity in Baldwin's Tell Me How Long the Train's Been Gone," Obsidian III: Literature in the African Diaspora, 9:2 (2008), pp. 62-76.

Pierpont, Claudia Roth, "Another Country: James Baldwin's Flight from America," The New Yorker, 9 February 2009, http://www.newyorker.com/magazine/2009/02/09/anothercountry (accessed 27 June 2016).

Polsgrove, Carol, Divided Minds: Intellectuals and the Civil Rights Movement (New York, W.W. Norton, 2001).

Reid-Pharr, Robert, Once You Go Black: Choice, Desire, and the Black American Intellectual (New York, New York University Press, 2007).

Shulman, George, American Prophecy: Race and Redemption in American Political Culture (Minneapolis, MN, University of Minnesota Press, 2008). 
Schur, Richard, "Unseen or Unspeakable? Racial Evidence in Baldwin's and Morrison's Nonfiction," in Lovalerie King and Lynn Orilla Scott (eds.), James Baldwin and Toni Morrison: Comparative Critical and Theoretical Essays (New York, Palgrave Macmillan, 2006), pp. 205-22.

Scott, Lynn Orilla, "Challenging the American Conscience, Re-Imagining American Identity: James Baldwin and the Civil Rights Movement," in Douglas Field (ed.), A Historical Guide to James Baldwin (Oxford, Oxford University Press, 2009), pp. 141-76.

_ James Baldwin's Later Fiction: Witness to the Journey (East Lansing, MI, Michigan State University Press, 2002).

"Revising the Incest Story: Toni Morrison's The Bluest Eye and James Baldwin's Just Above My Head," in Lovalerie King and Lynn Orilla Scott (eds.), James Baldwin and Toni Morrison: Comparative Critical and Theoretical Essays (New York, Palgrave Macmillan, 2006), pp. 83-102.

Spurlin, William J., "Rethinking the Politics of Race, Gender and Sexuality: The Critical Reception of Baldwin's Go Tell It on the Mountain in the Cold War Imaginary and in US Black Nationalism," MAWA Review, 19:1 (2004), pp. 58-70.

Stockton, Kathryn Bond, Beautiful Bottom, Beautiful Shame: Where "Black" Meets "Queer" (Durham, N.C., Duke University Press, 2006).

Thorsen, Karen, et al. (dirs.), James Baldwin: The Price of the Ticket (San Francisco, California Newsreel, 1989).

Traylor, Eleanor, "I Hear Music in the Air: James Baldwin's Just Above My Head", in Quincy Troupe (ed.), James Baldwin: The Legacy (New York, Touchstone-Simon and Schuster, 1989), pp. 95-106.

Tuhkanen, Mikko, "Binding the Self: Baldwin, Freud, and the Narrative of Subjectivity," GLQ: A Journal of Lesbian and Gay Studies, 7:4 (2001), pp. 553-91.

Walker, Will, "After the Fire Next Time: James Baldwin's Postconsensus Double Bind," in Eddie S. Glaude Jr. (ed.), Is It Nation Time? (Chicago, University of Chicago Press, 2002), pp. 215-33.

Zaborowska, Magdalena J., "In the Same Boat': James Baldwin in the Other Atlantic," in Douglas Field (ed.), A Historical Guide to James Baldwin (Oxford, Oxford University Press, 2009), pp. 177-211.

— James Baldwin's Turkish Decade: Erotics of Exile (Durham, N.C., Duke University Press, 2009).

"Racing Transatlantic Passages: James Baldwin's African 'America' and Immigrant Studies," in Ramaswami Mahalingam (ed.), Cultural Psychology of Immigrants (Mahwah, N.J, Lawrence Erlbaum, 2006), pp. 169-96.

\section{Contributor's Biography}

Lynn Orilla Scott is Professor Emerita of Michigan State University. Her published work on James Baldwin includes James Baldwin's Later Fiction: Witness to the Journey (2002), James Baldwin and Toni Morrison: Comparative Critical and Theoretical Essays (co-edited with Lovalerie King, 2006), and "Challenging the American Conscience, Re-Imagining American Identity: James Baldwin and the Civil Rights Movement” (2009). 